\title{
A randomized controlled trial of vaginal misoprostol tablet and intracervical dinoprostone gel in labor induction of women with prolonged pregnancies
}

\section{Apurba Mandal ${ }^{1}$, Shibram Chattopadhyay ${ }^{1}$, Snehamoy Choudhuri ${ }^{2}$, Samaresh Malo ${ }^{1}$, Kajal Patra $^{3}$, Sharmistha Ganguly ${ }^{1}$, Debmalya Maiti ${ }^{1}$}

\author{
${ }^{1}$ Department of Gynaecology and Obstetrics, Nil Ratan Sircar (NRS) Medical College and Hospital, Kolkata 700014, \\ West Bengal, India \\ ${ }^{2}$ Department of Gynaecology and Obstetrics, Midnapur Medical College, West Bengal, India \\ ${ }^{3}$ Department of Gynaecology and Obstetrics, Bankura Sanmilani Medical College, Bankura, West Bengal, India
}

Received: 16 November 2015

Accepted: 12 December 2015

*Correspondence:

Dr. Shibram Chattopadhyay,

E-mail: shibramchatt@gmail.com

Copyright: (C) the author(s), publisher and licensee Medip Academy. This is an open-access article distributed under the terms of the Creative Commons Attribution Non-Commercial License, which permits unrestricted non-commercial use, distribution, and reproduction in any medium, provided the original work is properly cited.

\begin{abstract}
Background: Objective of the study was to compare the efficacy of vaginal misoprostol and intracervical dinoprostone gel for induction of labor in women with unfavorable cervix beyond 41 weeks (287 days) of gestation.

Methods: This randomized controlled trial was performed at a teaching hospital between January 2011 and December 2012. 192 women with singleton uncomplicated pregnancy with no previous uterine scar not going into spontaneous labor at 288th days of gestation .Misoprostol(25 mcg tablet)in the posterior vaginal fornix, four hourly, maximum six doses or Dinoprostone $(0.5 \mathrm{mg}$ gel) intracervical instillation ,six hourly, maximum three doses were given.Oxytocin was administered if needed. Primary outcome: Induction delivery interval (IDI) with incidence of delivery within 12 hours and 24 hours; mode of delivery: vaginal or caesarean section. Secondary outcome: maternal side effects, neonatal outcome. For statistical analysis chi-square test, student t- test and P-value determination were done.

Results: The mean IDI was shorter in the misoprostol group compared to the dinoprostone group $(p<0.001)$ with more delivery within $<12$ hours $(p<0.001)$ and within $<24$ hours $(p<0.05)$. Caesarean section rate was lower in misoprostol group compared to dinoprostone group (12.76\% versus $23.07 \%$ ) but this difference was not statistically significant $(\mathrm{p}>0.05)$. Adverse neonatal outcome (5-minutes Apgar score<7) with NICU admission was more in misoprostol group compared to dinoprostone group $(0.04 \%$ versus $0.01 \%)$ but this difference was also not statistically significant $(\mathrm{p}>0.05)$.

Conclusions: Vaginal misoprostol tablet is a safe and more effective method of induction of labour when compared with intracervical dinoprostone gel in prolonged pregnancies.
\end{abstract}

Keywords: Prolonged pregnancies, Induction of labour, Misoprostol, Dinoprostone, Apgar score

\section{INTRODUCTION}

The history of labour induction dated back to Hippocrates original descriptions of mammary stimulation and mechanical dilatation of the cervical canal. ${ }^{1}$ Conventionally and essentially arbitrarily, a pregnancy is considered to be "prolonged" after $41(+0)$ weeks of gestation. Prolonged pregnancies involve 15-20 $\%$ of pregnant women and post term pregnancies $[\geq 42(+0)$ weeks $]$ approximately $1 \%$. In prolonged pregnancies, especially the emergency caesarean section rate is multiplied by 1.5 (Grade B). From 37 (0-6) to 43 
(0-6) weeks, the risk of perinatal mortality increase regularly, from $0.7 \%$ to $5.8 \%$. Meconium aspiration syndrome is responsible for substantial morbidity and mortality, and its incidence increases regularly between $38(+0)$ and $42(+6)$ weeks, from $0.24 \%$ to $1.42 \%$ (Grade B). Similarly, the risks of neonatal acidosis ( Grade B), 5minutes APGAR score less than 7 (Grade B) and admissions to neonatal intensive care units (Grade B) increase progressively between $38(+0)$ and $42(+6)$ weeks. These risks appear to double for post-term growth-restricted newborns (Grade C). ${ }^{2}$ Unpublished data from the WHO global survey on maternal and perinatal death which included 373 health-care facilities in 24 countries and nearly 300,000 deliveries, showed that $9.6 \%$ of the deliveries involved labour induction. ${ }^{3}$ Recent studies have suggested that by continuing pregnancies beyond 41 weeks, there is a statistically significant higher perinatal morbidity and mortality as well as an increased risk to the mother. ${ }^{4,5}$ Thus, there is a growing body of evidence suggesting the elective induction of labour at 41 completed weeks of gestation instead of expectant management. ${ }^{6-8}$ In 1968, Karim \& colleagues were the first to report the use of prostaglandins for labour induction. . Since then, the use of prostaglandins, in different varieties and forms of administration, has become a common method of labour induction. ${ }^{10}$ More recently, a synthetic prostaglandin analogue misoprostol has gained acceptance as an effective and safe method of labour induction. ${ }^{11}$ Several studies have demonstrated a higher efficacy of vaginally administered misoprostol compared to vaginal dinoprostone for both cervical ripening and labour induction at the usual recommended doses. ${ }^{12}$ However, it is difficult to interpret previously published studies comparing misoprostol with dinoprostone for induction of labour since majority of them have included both complicated and uncomplicated pregnancies as well as a wide gestational age (GA) range (37-42 weeks). ${ }^{13-15}$ Moreover, to reduce the risk of side effects, one can either decrease the dose of the drug or prolong the dosage interval. In addition, Alexander et al, have recently shown that in prolonged pregnancies it was not the induction per se that would increase the risk for caesarean section (CS), but was the patients- related risk factors such as undilated cervix. ${ }^{16}$ This study was undertaken to compare the efficacy of vaginal misoprostol with that of intracervical dinoprostone in a well-homogenized cohort of prolonged pregnancies with an unfavourable cervix (Modified Bishop's score $\leq 5$ ) and without pregnancy complications.

\section{METHODS}

192 women with prolonged pregnancies at $288^{\text {th }}$ day of gestation were recruited in between January 1, 2013 and December 31, 2014 for the study at the labour ward in the department of Gynae and Obst, NRS medical college, Kolkata 700014, a tertiary care centre in West Bengal, India with about 10,000 deliveries a year. The ethical committee approved the study and all participants gave their written informed consent. A sequence from a computerized random number generator was used for the allocation of patients to each group: 96 women in misoprostol group (Group A) and 96 women in dinoprostone group (Group B).

\section{Inclusion criteria}

1. Age $\geq 18$ yrs old,

2. Accurate dating of gestation, including CRL measurements in the first trimester of pregnancy,

3. Singleton viable pregnancy,

4. Gestational age $>287$ days,

5. Cephalic presentation,

6. Unfavorable cervical status defined as modified Bishop's score $(\mathrm{BS}) \leq 5$,

7. Intact membranes,

8. Reactive Non- stress test (NST) after randomization

\section{Exclusion criteria}

1. Known contraindications to receiving prostaglandins,

2. Placenta Previa,

3. Prior uterine surgery and

4. Any antenatal complications

A Sample size calculation was performed on the assumption that misoprostol would differ more than $17 \%$ from dinoprostone in terms of induction to delivery interval. The average delivery interval in our institute is 18 hours approximately. On the basis of a type I error of 0.05 and a power of $80 \%$ (type II error 0.2 ), 96 women in both trial arm were required. After exclusions from intention-to-treat analysis, secondary 'protocol compliant' analysis was done with 94 women in the misoprostol group and 91 women in dinoprostone group (Figure 1).

Women allocated to the misoprostol group (Group A) received 25 mcgs of misoprostol tablet placed in the posterior fornix and was administered every 4 hours for a maximum of six doses. Women allocated to the dinoprostone group received $0.5 \mathrm{mg}$ of dinoprostone gel intracervically every six hours for a maximum of three doses. Intravaginal oxytocin augmentation was used after spontaneous or artificial rupture of membranes without adequate uterine contractions or failure to progress in active phase of labour. Partograph was performed from the moment women were considered to be in active phase of labour along with continuous fetal heart rate and uterine activity monitoring using CTG machines. Hyperstimulation syndrome was diagnosed whenever there was either uterine tachysystole ( $>5$ contractions per 10 minutes) or hypertonus (when one contraction lasted more than 2 minutes) was associated with the presence of non reassuring fetal heart rate patterns as persistent or recurring episodes of severe variable decelerations, late decelerations, prolonged fetal bradycardia or a combination of decreased beat- to- beat variability and a decelerative pattern. ${ }^{17}$ 


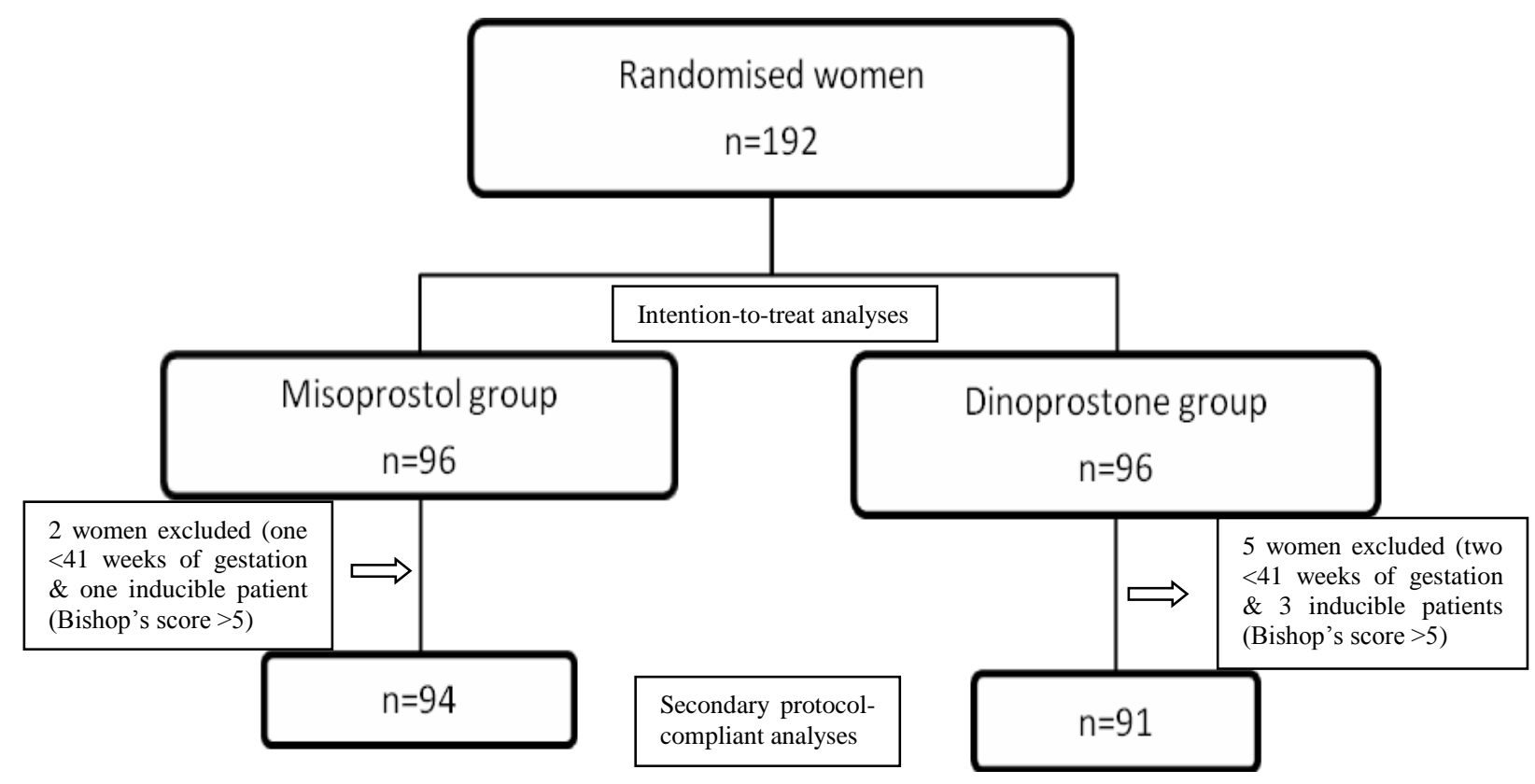

Figure 1: Patient flow chart.

The primary outcome measures were time from induction to delivery (IDI), incidence of delivery within 12 hours and 24 hours and mode of delivery whether vaginal or caesarean section. The secondary outcome measures were maternal side effects and need of neonatal resuscitation with evaluation of APGAR score at 1 minute and 5 minutes requiring NICU admission within 24 hours of delivery.

Statistical analysis was performed using SPSS version II software. The Chi- square tests $\left(\mathrm{x}^{2}\right)$ and the student-T tests were performed for nominal variations and normal distributed metric variables respectively. All tests were two tailed with a confidence level of $95 \% \quad(\mathrm{p}<0.05)$. Values are expressed as mean $+/$ - standard error (SEM) and the percentage of total number of samples.

\section{RESULTS}

The two groups were comparable in terms of demographic characteristics such as parity $\left(\mathrm{x}^{2}=0.61\right.$, $\mathrm{p}>0.05)$, socioeconomic status $\left(\mathrm{x}^{2}=2.21, \mathrm{p}>0.05\right)$ and prenatal visits $\left(x^{2}=0.25, p>0.05\right)$ except age of women where statistically significant differences were found $\left(\mathrm{x}^{2}\right.$ $=9.02 \mathrm{df}=2, \mathrm{p}<0.05)$ as depicted in Table 1 .

In Table 2 the primary outcome showing the induction to delivery time interval expressed as mean hours \pm SEM was statistically significantly different in 2 groups $(\mathrm{t}=79.17, \mathrm{df}=183, \mathrm{p}<0.05)$ showing more delivery within 12 hours in the misoprostol group $\left(\mathrm{x}^{2}=38.46, \mathrm{p}<0.05\right)$ and within 24 hours also $\left(x^{2}=4.98, \mathrm{p}<0.05\right)$ in comparison to dinoprostone group. The occurrences of caesarean section is less in group A in comparison with group B (12.76\% vs $23.07 \%)$ although that is not statistically significant $\left(\mathrm{x}^{2}\right.$ $=3.35, \mathrm{p}>0.05)$.
Table 1: Demographic characteristics.

\begin{tabular}{|c|c|c|c|c|}
\hline No & & $\begin{array}{l}\text { Group A } \\
(n=94)\end{array}$ & $\begin{array}{l}\text { Group B } \\
(\mathrm{n}=91)\end{array}$ & $\begin{array}{l}\text { Statistical } \\
\text { significance }\end{array}$ \\
\hline \multirow[t]{4}{*}{1} & Age (years) & No $(\%)$ & No $(\%)$ & \\
\hline & $</=19$ & $\begin{array}{l}15 \\
(15.96 \%)\end{array}$ & $\begin{array}{l}32 \\
(35.16 \%)\end{array}$ & $\mathrm{df}=2$ \\
\hline & $20-25$ & $\begin{array}{l}58 \\
(61.70 \%)\end{array}$ & $\begin{array}{l}44 \\
(48.35 \%)\end{array}$ & $x^{2}=9.02$ \\
\hline & $>/=26$ & $\begin{array}{l}21 \\
(22.34 \%)\end{array}$ & $\begin{array}{l}15 \\
(16.48 \%)\end{array}$ & $\begin{array}{l}\mathrm{P}=0.0109 \\
(\mathrm{~S})\end{array}$ \\
\hline \multirow[t]{3}{*}{2} & Parity & & & \\
\hline & $\begin{array}{l}\text { Primig- } \\
\text { ravida }\end{array}$ & $\begin{array}{l}65 \\
(69.14 \%)\end{array}$ & $\begin{array}{l}58 \\
(63.73 \%)\end{array}$ & $x^{2}=0.61$ \\
\hline & $\begin{array}{l}\text { Multi- } \\
\text { gravida }\end{array}$ & $\begin{array}{l}29 \\
(30.85 \%)\end{array}$ & $\begin{array}{l}33 \\
(36.26 \%)\end{array}$ & $\begin{array}{l}\mathrm{P}=0.436 \\
(\mathrm{NS})\end{array}$ \\
\hline \multirow[t]{4}{*}{3} & Socio-econon & lic status & & \\
\hline & $\begin{array}{l}\text { Poor class } \\
(</=\text { Rs.6,00 } \\
0 / \text { month })\end{array}$ & $\begin{array}{l}65 \\
(69.14 \%)\end{array}$ & $\begin{array}{l}71 \\
(78.02 \%)\end{array}$ & $x^{2}=2.21$ \\
\hline & $\begin{array}{l}\text { Middle } \\
\text { class } \\
\text { (</=Rs. } 60,0 \\
00 / \text { month })\end{array}$ & $\begin{array}{l}23 \\
(24.46 \%)\end{array}$ & $\begin{array}{l}17 \\
(18.68 \%)\end{array}$ & $\mathrm{df}=2$ \\
\hline & $\begin{array}{l}\text { Higher } \\
\text { class } \\
\text { (>Rs.60,00 } \\
\text { 0/month) }\end{array}$ & $\begin{array}{l}6 \\
(06.38 \%)\end{array}$ & $\begin{array}{l}3 \\
(03.29 \%)\end{array}$ & $\begin{array}{l}\mathrm{P}=0.347 \\
(\mathrm{NS})\end{array}$ \\
\hline \multirow[t]{3}{*}{4} & Prenatal visit & & & \\
\hline & $<3$ & $\begin{array}{l}13 \\
(13.83 \%)\end{array}$ & $\begin{array}{l}15 \\
(16.48 \%)\end{array}$ & $x^{2}=0.25$ \\
\hline & $>/=3$ & $\begin{array}{l}81 \\
(86.17 \%)\end{array}$ & $\begin{array}{l}76 \\
(83.52 \%)\end{array}$ & $\begin{array}{l}\mathrm{P}=0.615 \\
(\mathrm{NS})\end{array}$ \\
\hline
\end{tabular}


Table 2: Primary outcome.

\begin{tabular}{|c|c|c|c|c|}
\hline \multicolumn{2}{|l|}{ No } & Group A ( $(n=94)$ & Group B (n=91) & Statistical significance \\
\hline \multirow[t]{3}{*}{1} & $\begin{array}{l}\text { Induction -delivery interval (IDI) } \\
\text { (Mean hours +/-SEM) }\end{array}$ & $10.8 \pm 0.7$ & $18.4 \pm 0.6$ & $\mathrm{t}=79.17, \mathrm{df}=183 \mathrm{p}=0.000(\mathrm{~S})$ \\
\hline & A) Delivery $<12$ hours & $61(\overline{64.89 \%)}$ & $18(19.78 \%)$ & $\mathrm{x}^{2}=38.46, \mathrm{p}=0.000(\mathrm{~S})$ \\
\hline & B) Delivery <24 hours & $92(97.87 \%)$ & $82(90.11 \%)$ & $\mathrm{x}^{2}=4.98, \mathrm{p}=0.025(\mathrm{~S})$ \\
\hline \multirow[t]{9}{*}{2} & Mode of delivery & & & \\
\hline & A) Vaginal & $82(87.23 \%)$ & $70(76.92 \%)$ & \\
\hline & a) Spontaneous & 78 & 67 & \\
\hline & b) Instrumental & 04 & 03 & \\
\hline & B) Caesarean & $12(12.76 \%)$ & $21(23.07 \%)$ & $\mathrm{x}^{2}=3.35, \mathrm{p}=0.0670(\mathrm{NS})$ \\
\hline & a) $\mathrm{CPD}$ & 0 & 1 & \\
\hline & b) Fetal distress & 8 & 11 & \\
\hline & c) Non-progress of labour & 2 & 5 & \\
\hline & d) Failed induction (IDI >24hours) & 2 & 4 & \\
\hline
\end{tabular}

Table 3: Labour events.

\begin{tabular}{|c|c|c|c|c|}
\hline \multicolumn{2}{|l|}{ No } & Group A ( $n=94)$ & Group B (n=91) & Statistical significance \\
\hline \multirow{2}{*}{1} & IDI according to parity (mean hours +/-SEM) & & & \\
\hline & Primigravida & $11.9 \pm 0.4$ & $21.7 \pm 0.7$ & \multirow{2}{*}{$\begin{array}{l}\mathrm{t}=117.38, \mathrm{df}=183 \\
\mathrm{P}=0.000(\mathrm{~S})\end{array}$} \\
\hline & Multigravida & $8.2+/-0.6$ & $12.4+/ 0.6$ & \\
\hline 2 & $\begin{array}{l}\text { Time of reaching active phase of labour } \\
\text { from induction (mean } \mathrm{hr} \pm \text { SEM) }\end{array}$ & $6.8 \pm 0.4$ & $14.3 \pm 0.9$ & $\begin{array}{l}\mathrm{t}=73.64 \\
\mathrm{df}=183, \mathrm{p}=0.000(\mathrm{~S})\end{array}$ \\
\hline 3 & Need for oxytocin augmentation & $33(35.10 \%)$ & $69(75.82 \%)$ & $\mathrm{x}^{2}=30.99, \mathrm{p}=0.000(\mathrm{~S})$ \\
\hline 4 & Spontaneous rupture of membranes & $42(44.68 \%)$ & $18(19.78 \%)$ & $\mathrm{x}^{2}=13.08, \mathrm{p}=0.0002(\mathrm{~S})$ \\
\hline \multirow[t]{4}{*}{5} & No. of doses needed & & & \\
\hline & a) Single & $75(79.78 \%)$ & $58(63.73 \%)$ & \multirow{3}{*}{$\begin{array}{l}\mathrm{x}^{2}=8.46, \mathrm{df}=2 \\
\mathrm{P}=0.0146(\mathrm{~S})\end{array}$} \\
\hline & b) Second & $16(17.02 \%)$ & $32(35.16 \%)$ & \\
\hline & c) Third & $03(03.19 \%)$ & $1(01.09 \%)$ & \\
\hline 6 & Meconium stained amniotic fluid (MSAF) & $28(29.78 \%)$ & $16(17.58 \%)$ & $\mathrm{x}^{2}=3.8, \mathrm{P}=0.051(\mathrm{NS})$ \\
\hline 7 & Abnormal FHR & $20(21.27 \%)$ & $8(08.79 \%)$ & $\mathrm{x}^{2}=4.21, \mathrm{P}=0.40(\mathrm{NS})$ \\
\hline 8 & Uterine hyperstimulation syndrome & $6(06.38 \%)$ & $3(03.29 \%)$ & $\mathrm{x}^{2}=0.95, \mathrm{P}=0.329(\mathrm{NS})$ \\
\hline
\end{tabular}

Table 3 showing labour events as follows: IDI were statistically significantly different between the groups both in primigravida $(\mathrm{t}=17.38$, df $=183, \mathrm{p}<0.05)$ and in multigravida $(\mathrm{t}=47.6, \mathrm{df}=183, \mathrm{p}<0.05)$. The time to reach active phase of labour from the time of starting of induction of labour was significantly less in misoprostol group $(\mathrm{t}=73.64, \mathrm{df}=183, \mathrm{p}<0.05)$ while need for oxytocin augmentation was significantly more in dinoprostone group $\left(x^{2}=30.99, p<0.05\right)$. The incidence of spontaneous rupture of membranes were significantly more in group A $\left(\mathrm{x}^{2}=13.08, \mathrm{p}<0.05\right)$. The need of repeated doses were also statistically significantly different between two groups $\left(\mathrm{x}^{2}\right.$ $=8.46, \mathrm{df}=2, \mathrm{p}<0.05)$. The occurrence of meconium stained amniotic fluid (MSAF), abnormal fetal heart rate changes and incidences of uterine hyperstimulation syndrome were more in misoprostol group than dinoprostone group but were not statistically significant.

In Table 4, the secondary outcomes showing adverse effects due to prostaglandin use were seen in $8.51 \%$ cases of misoprostol group only and no one in the dinoprostone group was suffering from G.I side effects like vomiting, diarrhoea etc. There was only one case of atonic PPH occurred in dinoprostone group and she received blood transfusion along with uterotonic drugs without surgical intervention. The incidences of vaginal tear were more in group A $\left(5.32 \%\right.$ versus $\left.2.19 \%, \mathrm{x}^{2}=1.24, \mathrm{p}>0.05\right)$ and puerperal sepsis occurred more in group B (4.25\%versus $\left.8.79 \%, x^{2}=2.15, p>0.05\right)$. Significantly different mean birth weight of newborns were seen between the groups (2775+/-530grams vs 2532+/-450grams; $t=3.36, d f=183$, $\mathrm{p}<0.05)$. The need for neonatal resuscitation was significantly more in group A $\left(\mathrm{x}^{2}=5.25, \mathrm{p}<0.05\right)$ while more neonates in the misoprostol group had lower APGAR score of $<7$ at one minute $\left(\mathrm{x}^{2}=4.67, \mathrm{p}<0.05\right)$ and at 5 minutes $\left(\mathrm{x}^{2}=1.75, \mathrm{p}=0.186\right)$ needed NICU admissions but that difference was not statistically significant when compared to dinoprostone group. 
Table 4: Secondary outcome.

\begin{tabular}{|c|c|c|c|c|}
\hline No & & $\begin{array}{l}\text { Group A } \\
(\mathrm{n}=94)\end{array}$ & $\begin{array}{l}\text { Group B } \\
(\mathrm{n}=91)\end{array}$ & $\begin{array}{l}\text { Statistical } \\
\text { significance }\end{array}$ \\
\hline \multirow[t]{5}{*}{1} & Maternal & & & \\
\hline & $\begin{array}{l}\text { a) G.I side } \\
\text { effects }\end{array}$ & $\begin{array}{l}8 \\
(08.51 \%)\end{array}$ & 0 & \\
\hline & $\begin{array}{l}\text { b) } \mathrm{PPH} \\
\text { (Atonic) }\end{array}$ & 0 & $\begin{array}{l}1 \\
(01.09 \%)\end{array}$ & \\
\hline & $\begin{array}{l}\text { c) Vaginal } \\
\text { tear }\end{array}$ & $\begin{array}{l}5 \\
(05.32 \%)\end{array}$ & $\begin{array}{l}2 \\
(02.19 \%)\end{array}$ & $\begin{array}{l}x^{2}=1.24, p=0 \\
266(N S)\end{array}$ \\
\hline & $\begin{array}{l}\text { d) Puerperal } \\
\text { sepsis }\end{array}$ & $\begin{array}{l}4 \\
(04.25 \%)\end{array}$ & $\begin{array}{l}8 \\
(08.79 \%)\end{array}$ & $\begin{array}{l}x^{2}=2.15, p=0 \\
142(N S)\end{array}$ \\
\hline \multirow[t]{2}{*}{2} & Neonatal & & & \\
\hline & $\begin{array}{l}\text { a) Birth } \\
\text { weight } \\
\text { (grams) }\end{array}$ & $\begin{array}{r}2775 \\
+530\end{array}$ & $\begin{array}{r}2532 \\
+450\end{array}$ & $\begin{array}{l}\mathrm{t}=3.36, \mathrm{df}=18 \\
3 \\
\mathrm{p}=0.001(\mathrm{~S})\end{array}$ \\
\hline 2 & $\begin{array}{l}\text { Neonatal } \\
\text { resuscitation }\end{array}$ & $\begin{array}{l}15 \\
(15.95 \%)\end{array}$ & $\begin{array}{l}5 \\
(05.49 \%)\end{array}$ & $\begin{array}{l}\mathrm{x}^{2}=5.25, \mathrm{p}=0 \\
0219(\mathrm{~S})\end{array}$ \\
\hline \multirow[t]{3}{*}{3} & APGAR scor & & & \\
\hline & at 1 minute & $\begin{array}{l}11 \\
(11.70 \%)\end{array}$ & $\begin{array}{l}3 \\
(03.29 \%)\end{array}$ & $\begin{array}{l}x^{2}=4.67 p=0.0 \\
307(S)\end{array}$ \\
\hline & at 5 minutes & $\begin{array}{l}4 \\
(04.25 \%)\end{array}$ & $\begin{array}{l}1 \\
(01.09 \%)\end{array}$ & $\begin{array}{l}x^{2}=1.75, p=0 \\
0186(N S)\end{array}$ \\
\hline 4 & $\begin{array}{l}\text { NICU } \\
\text { admission }\end{array}$ & $\begin{array}{l}4 \\
(04.25 \%)\end{array}$ & $\begin{array}{l}1 \\
(01.09 \%)\end{array}$ & $\begin{array}{l}x^{2}=1.75, p=0 \\
0186(N S)\end{array}$ \\
\hline
\end{tabular}

\section{DISCUSSION}

Induction of labour is more widely used than ever before, nowadays, for both maternal and fetal indication. ${ }^{18}$ One of the most common indications is prolonged pregnancy. ${ }^{19}$ Women may experience distress when labour has not started by the expected date and obstetricians have to withstand pressure from these patients as well as the temptation to use prostaglandins earlier. Appropriate evaluation of the pregnancy and consultation with such patients will lead to the correct selection to those who will benefit most from a labour induction, thus eliminating the risk of post maturity to the fetus without inducing fetal distress during labour. In these carefully selected cohort of patients, misoprostol at the dose used not only shortened the time between induction and delivery (10.8 hrs vs $18.4 \mathrm{hrs})$ in comparison with dinoprostone but this result was achieved with low CS rate $(12.76 \%$ vs $23.07 \%)$ respectively. A difference of $10 \%$ in favour of misoprostol, although not statistically significant, might have clinical importance in terms of patient health and cost effectiveness as supported by a study by Sanchez - Ramos et al. ${ }^{20}$ With misoprostol, there was an increased incidence of MSAF as well as hyperstimulation syndrome than dinoprostone but the CS rate is lower and though APGAR score $<7$ at 5 minutes with NICU admission were higher but that are not statistically significant, a finding in favour of misoprostol not seen in previous studies like a study by Blanchard $\mathrm{K}$ et al. $^{21}$ As with other studies, lesser number of participants with misoprostol induction required augmentation of labour with oxytocin as compared to dinoprostone gel. ${ }^{22}$ So, it is evident that vaginal misoprostol is more effective than intracervical dinoprostone gel.

\section{CONCLUSIONS}

Vaginally administered tablet misoprostol is a safe and more effective method of induction of labour when compared with intracervical dinoprostone gel in prolonged pregnancies beyond 41 weeks of gestation as adverse perinatal outcomes are not disproportionately increased if timely intervention is done with adequate and appropriate surveillance.

\section{ACKNOWLEDGEMENTS}

The authors would like to thank all the women who participated in the trial, the doctors and nurses in the labour ward and NICU, whose involvement made this study possible. Finally, the authors also express their deep gratitude to Dr. Tushar Kanti Saha, Assistant professor, Dept. of Community Medicine, NRS Medical College \& Hospital, for doing statistical analysis of the study.

Funding: No funding sources

Conflict of interest: None declared

Ethical approval: The study was approved by the Institutional Ethics Committee

\section{REFERENCES}

1. De Ribes C. De l' Accouchement Provoque, Dilatation du canal Genital a l'Aide de Ballons Introduits dans la Cavite Uterine Pendant La Grossesse. Paris, Steinheil. 1988.

2. Prolonged and post-term pregnancies. Guidelines for clinical practice from CNGOF. Vayssiere C, Haumonte JB, Chantry A, et al. Eur J Obstet Gynecol Reprod Biol. 2013 Feb 20.

3. WHO Global Survey on Maternal and Perinatal Health. Induction of labour data. Geneva, World Health Organization. 2010. (available at: http:// www.who.int/reproductivehealth/topics/best_practice s/global _ survey)

4. Hilder L, Costeloe K, Thilaganathan B. Prolonged preganancy: Evaluating gestation specific risks of fetal and infant mortality. Br J Obstet Gynecol. 1998;105:169-73.

5. Cotzias CS, Paterson- Brown S, Fisk NM. Prospective risk of unexplained stillbirth in singleton pregnancies at term: population based analysis. BMJ. 1999;319:287-98.

6. Rand L, Robinson JN, Economy KE, Norwitz ER. Post term induction of labour revisited. Obstet Gynecol. 2000;96:779-83.

7. Hannah ME, Hannah WJ, Hellmann J, Hewson S, Milner R, Willan A. Induction of labour as compared with serial antenatal monitoring in post term pregnancy- A randomized controlled trial. The 
Canadian Multicenter Post-term Pregnancy Trial Group. N Engl J Med. 1992;326:1587-92.

8. Crowley $\mathrm{P}$. Interventions for preventing or improving the outcome of delivery at or beyond term. Cochrane Database Syst Rev. 2000:CD 000170.

9. Karim SMM, Trussele RR, Patel RC, Hillier K. Response of pregnant human uterus to prostaglandin F2 alpha, Induction of labour. BMJ. 1968;4:621-3.

10. Keirse MJNC. Prostaglandins in preinduction cervical ripening. Meta analysis of world- wide clinical experience. J Reprod Med. 1993;38:69-98.

11. Sanchez-Ramos L, Kaunitz AM, Delvalle GO. Labor induction with the prostaglandin E 1 methyl analogue misoprostol versus oxytocin: a randomized trial.Obstet Gynecol. 1993;81:332-6.

12. Hofmeyr GJ, Gulmezoglu AM. Vaginal misoprostol for cervical ripening and labour induction in late pregnancy (Cochrane review).The Cochrane Library Issue 3\&4 Oxford: Cochrane update software. 2000 $\& 2002$.

13. Le Roux PA, Olarogun JO, Penny J, Anthony J. Oral and vaginal misoprostol compared with dinoprostone for induction of labour. a randomized controlled trial. Obstet Gynecol. 2002;99:201-5.

14. kolderup L, McLean L, Grullon K, Safford K, Kilpatrick S: Misoprostol is more efficacious for labour induction than prostaglandin E2, but is it associated with more risk? Am J Obstet Gynecol. 1999;180:1543-50.

15. Buser D, More G, Arias F. A randomized comparison between misoprostol and dinoprostone for cervical ripening and labour induction in patients with unfavourable cervices.Obstet Gynecol. 1997;89:581-5.

16. Alexander JM, McIntire DD, Leveno KJ. prolonged pregnancy:induction of labour and caesarean births. Obstet Gynecol. 2001,97:911-5 .

17. American College of Obstetricians and Gynecologists: Fetal heart rate patterns; monitoring, interpretation and management. ACOG practice Bulletin no.207 Washington DC: ACOG. 1995.

18. Rayburn WF, Zhang J. Rising rates of labour induction: present concern and future strategies. Obsteet Gynecol. 2002;100:164-7.

19. Yahn BP, Wollan P, McKeon K, Field CS. Temporal changes in rates and reasons for medical induction of term labour. Am J Obstet Gynecol. 2001;184:611-9.

20. Sanchez-Ramos L, Kaunitz AM, Wears RL, Delke I, Gaudier FL. misoprostol for cervical ripening and labour induction : a meta analysis.Obstet Gynecol. 1997;89:633-42.

21. Blanchard K, Clark S, Winikoff B, Gaines G, Kabani G, Shannon C. Misoprostol for women's health: A Review .Obstet Gynecol. 2002;99:316-22.

22. Shivarudraiah G, Palaksha MA. A randomized controlled trial comparing low dose vaginal misoprostol and dinoprostone gel for labour induction. J Obstet Gynecol Ind. 2011:61(2):153-60.

Cite this article as: Mandal A, Chattopadhyay S, Choudhuri S, Malo S, Patra K, Ganguly S, Maiti D. A randomized controlled trial of vaginal Misoprostol tablet and intracervical dinoprostone gel in labor induction of women with prolonged pregnancies. Int J Reprod Contracept Obstet Gynecol 2016;5:343-8. 